\title{
A New Alternative to Measure Students' Analytical Thinking Skill: A Validity Test for Mechanics Problem Based Learning Module
}

\author{
Yashinta Putri Sekarini ${ }^{1,}$, Endang Tri Adiningsih ${ }^{1}$, Zulfa Lutfi Anisa ${ }^{1}$, Bayu \\ Setiaji $^{1}$
}

\begin{abstract}
${ }^{1}$ Physics Education, Faculty of Mathematics and Science, Universitas Negeri Yogyakarta, Colombo Street No.1, Karang Malang, Caturtunggal, Depok, Sleman, Yogyakarta 55281, Indonesia

*Corresponding author. Email: yashintaputri.2019@student.uny.ac.id
\end{abstract}

\begin{abstract}
This study is aimed to produce a Mechanics Problem Based Learning module, that is feasible to use in physics learning on Mechanics topic. The research method uses Research and Development (RnD). The instruments are questionnaires of module feasibility test and questions validity test. The validators are a construct validator from physics education lecturer and five content validators from pure physics lecturers. All validators are chosen from three state universities in Indonesia. The questions in this module fulfill the analytical thinking skill indicators based on Bloom's Taxonomy. The result of the module feasibility test is analyzed by using the Ideal Evaluation Criteria in Scale 5. Meanwhile, the result of the questions validity test is analyzed by using content validation ratio (CVR). Due to the result of the study, the Mechanics Problem Based Learning module is generally feasible to be used in physics learning on Mechanics topic. Owing to the general score of 4.06 out of 5.00 acquired, the module is included in the feasible category. Whereas the set of questions in the module is valid because it is included very useful category. All sub-indicators obtain CVR score of 1 as a perfect score. The module is revised based on validators' comments and adapted to the theory. Therefore, both the materials and the set of questions could be used to measure students' analytical thinking skill in physics learning on Mechanics topic.
\end{abstract}

Keywords: physics, Mechanics, Problem Based Learning, analytical thinking skills.

\section{INTRODUCTION}

The development of science and technology is quickly increasing various challenges in human life. Tight global competition requires human resources who have 21 st-century skills. The 21 st-century skills consist of many indicators, one of them is analytical thinking skill [1][2]. The analytical thinking skill of Indonesian students is still low. This could be observed by the result of the Programmed Program for International Student Assessment (PISA) in 2018 which was attended by 79 countries, included Indonesia. From the study result, Indonesia is in the bottom line for either mathematics or science category [3][4].
Analytical thinking skills in physics are needed to solve problems in daily life [5][6]. Bloom's taxonomy analytical thinking skill is included in the cognitive domain of $\mathrm{C} 4$ at the High-Level Thinking Skills (HOTS) level [7][8]. Problem Based Learning (PBL) is a module discussing problems in learning thus students could improve analytical thinking skills [9][10]. Wherefore PBL could be used to measure students' analytical thinking skills. It could be concluded that the PBL model is feasible to be used in physics learning. 


\section{LITERATURE REVIEW}

\subsection{Problem Based Learning (PBL) Module}

A module is a teaching material arranged systematically and easily understood [11]. The module also contains all related learning material. The module is adapted to the age and level of knowledge of the students thus they could study independently. The module should not depend on other teaching materials to teach students to learn independently. The module instructions are simple, easy-to-understand, and use commonly used terms [12][13]. Wherefore the module is a teaching material systematically compiled by the teacher in simple and easy-to-understand instructions and the module does not depend on other teaching materials.

Problem Based Learning (PBL) module is written based on Arends [14]. This module contains the main components of PBL, which is daily-life-problems [15]. The Theory of Constructivism pointed out that Problem Based Learning (PBL) emphasizes the existence of interdisciplinary problems to habituate students becoming lifelong learners [16][17]. By using problem-solving in everyday life, the PBL module could improve 21st-century skills [18][19]. The 21stcentury skills consist of think critically, analytically, and creatively [20]. As a result, problem-solving questions in PBL require the students to use analytical thinking skills so the student would have 21st-century skills.

The characteristics of PBL are problem-centered, student-centered, self-directed (students generalize learning problems and processes), self-reflective (students monitor their understanding and set their learning strategies), and the teacher serves as a facilitator [21]. The syntaxes of the PBL are implemented on the Mechanics Problem Based Learning module. The syntaxes complying with Arends [22] could be formulated as follows. First, orienting students to the problems is presented in Phase I on each question in this module. It has an introduction story about a physics problem in daily life. Second, organizing students to study is presented in Phase II on each question in the module. It has instructions for students to define and organize the problem. Third, guiding individual and group investigations should be provided to collect appropriate information, carry out experiments to get explanations and solutions to problems. But, this module actually does not contain this step because the investigation should use teaching media out of the module, such as virtual lab. It causes a difference with the theoretical basis, namely the module should not have to be used together with other teaching materials [12][13]. Fourth, developing and presenting result is presented in Phase III each question in the module. It has instructions to make a solution for each problem [22]. Fifth, analyzing and evaluating the problemsolving process by a reflection or evaluation is also not be contained in this module. Reflection or evaluation of the problem-solving process should be held by the teacher in real lesson in the school. Consequently, the Mechanics Problem Based Learning module has only accomplished the first step, the second step, and the fourth step of the syntaxes of the PBL.

\subsection{Analytical Thinking Skill}

The analytical thinking skill is a skill of simplifying a concept into smaller parts, then searching relationships between parts and gaining an understanding of a concept [23]. Analytical thinking skill has a higher level than remembering, understanding, and applying in taxonomies in the cognitive field [24][25]. Hence, analytical thinking skill is a higher level of understanding by simplifying a concept into smaller parts connecting all parts, and make the solution.

This module could be used to measure analytical thinking skills by presenting problem-solving questions. By problem-solving questions, students are encouraged to use analytical thinking skills through 3 (three) levels obeying Bloom's taxonomy [26]. First, students would pass the elemental analysis when they could divide a problem into several parts to identify them in detail. Second, students would pass the relation analysis when they could explain the relationship between one part to another part of the problem. Third, students would pass the analysis of organizing principles when students could make solutions to problem-solving questions and communicate the result of problem-solving. If students could pass these 3 levels, students could use analytical thinking skills. In consequence, it would be important to present problem-solving problems in this module. The questions in this module have been made using a classification of three analytical thinking skill levels following Bloom's taxonomy.

\section{RESEARCH METHODS}

This research study conducted uses Research and Development (R\&D) type based on 4D model, namely define, design, develop and disseminate [27]. This research study accomplishes defining, designing, and developing steps. The purpose of this study is to 
produce a Mechanics Problem Based Learning module that is feasible to use in physics learning on Mechanics topic. The final result of this study is Mechanics Problem Based Learning module. For measuring Mechanics Problem Based Learning module, the module validity instruments are questionnaires of module feasibility test and questions validity test. The set of questions in the module ought to fulfill analytical thinking skills based on Bloom's Taxonomy by providing a writing outline of each question. The questionnaires are sent online to six expert validators. The six validators are six physics lecturers from three state universities in Indonesia. The selection of these validators is according to the theoritical basis of construct validation and content validation. Construct validation is carried out by educational lecturers who are experts in the field of evaluation or teaching materials, and content validation (physics) is carried out by pure lecturers who are experts in the field of concepts being made.

\subsection{Data Collection Techniques and Instruments}

Table 1. Questionnaire indicators of the module feasibility test

\begin{tabular}{|c|c|}
\hline Aspect & Indicator \\
\hline \multirow[t]{10}{*}{ Contents } & $\begin{array}{l}\text { 1. The feasibility of module } \\
\text { objectives and learning objectives. }\end{array}$ \\
\hline & $\begin{array}{l}\text { 2. The essential of materials and } \\
\text { tasks. }\end{array}$ \\
\hline & $\begin{array}{l}\text { 3. The feasibility of material and } \\
\text { details with PBL syntax. }\end{array}$ \\
\hline & $\begin{array}{l}\text { 4. The feasibility of problem } \\
\text { orientation with purpose. }\end{array}$ \\
\hline & Guiding on problem formulation. \\
\hline & $\begin{array}{l}\text { 6. Guiding for the formulation of } \\
\text { hypotheses. }\end{array}$ \\
\hline & Complete tools and materials. \\
\hline & 8. $\quad$ Providing report format. \\
\hline & Providing feasible questions. \\
\hline & $\begin{array}{l}\text { 10. Arrangement of activities supports } \\
\text { scientific literacy skills. }\end{array}$ \\
\hline
\end{tabular}

\begin{tabular}{|c|c|c|}
\hline & & $\begin{array}{l}\text { The preparation of activities } \\
\text { supports analytical thinking skills. }\end{array}$ \\
\hline & 12. & $\begin{array}{l}\text { The feasibility of the writing } \\
\text { manner used in the module. }\end{array}$ \\
\hline & 13. & $\begin{array}{l}\text { The clarity and effectiveness of the } \\
\text { images used. }\end{array}$ \\
\hline & 14. & $\begin{array}{l}\text { Modules could encourage } \\
\text { students to use the scientific } \\
\text { method. }\end{array}$ \\
\hline \multirow[t]{4}{*}{ Language } & 15. & $\begin{array}{l}\text { Language features used are } \\
\text { according to the rules of proper } \\
\text { Indonesian language. }\end{array}$ \\
\hline & 16. & $\begin{array}{l}\text { The language features used are } \\
\text { communicative. }\end{array}$ \\
\hline & 17. & $\begin{array}{l}\text { The simplicity of sentence } \\
\text { structure. }\end{array}$ \\
\hline & 18. & $\begin{array}{l}\text { The sentences used are easy to } \\
\text { understand. }\end{array}$ \\
\hline
\end{tabular}

The questionnaire of questions validity test consists of 5 indicators, there are feasibility of content and existing indicators, completeness of the instruments, construction, feasibility of content, and language. Details of each indicator of the questionnaire are presented in Table 2. 
Table 2. Indicators of the questionnaire of question validity test

\begin{tabular}{|l|ll|}
\hline Language & $\begin{array}{l}\text { 1. } \\
\text { Obeying the rules of proper and } \\
\text { appropriate } \\
\text { language }\end{array}$ \\
\cline { 2 - 3 } 2. & Using communicative language. \\
\cline { 2 - 3 } 3. & $\begin{array}{l}\text { The language sentences is clear, } \\
\text { so it would not cause multiple } \\
\text { interpretations }\end{array}$ \\
\end{tabular}

\subsubsection{Data analysis}

The result of the questionnaire of the module feasibility test is analyzed using the Ideal Evaluation Criteria in Scale 5 by Azwar [28].

Table 3. Ideal Evaluation Criteria in Scale 5

\begin{tabular}{|c|l|}
\hline Quantitative Score Range & \multicolumn{1}{|c|}{ Category } \\
\hline$X>\overline{X \imath}+1,8 S B i$ & Very Feasible \\
\hline$\overline{X \imath}+0,6 S B i<X \leq \overline{X \imath}+1,8 S B i$ & Feasible \\
\hline$\overline{X \imath}-0,6 S B i<X \leq \overline{X \imath}+0,6 S B i$ & Quite Feasible \\
\hline$\overline{X \iota}-1,8 S B i<X \leq \overline{X \imath}+0,6 S B i$ & Less Feasible \\
\hline$X \leq \overline{X \imath}-1,8 S B i$ & Very Less \\
& Feasible \\
\hline
\end{tabular}

$X$ is the score, $\overline{X l}$ is $\frac{1}{2}$ (ideal maximum score + ideal minimum score). The ideal maximum score is sum of items criteria time highest score, and the minimum ideal score is sum of items criteria time the lowest score. SBi is $\frac{1}{6}$ the maximum ideal score minus the minimum ideal score.

The result of the questionnaire validity test is analyzed using the content validation ratio (CVR) technique developed by Lawshe [29]. The calculation is as follows.

$$
C V R=\left(\frac{n_{e}-\frac{N}{2}}{\frac{N}{2}}\right)
$$

CVR is the content validity ratio, $\mathrm{n}_{\mathrm{e}}$ is the number of validators asserting that items could be used, and $\mathrm{N}$ is the total number of validators. The analytical method of questions validity test refers to the categorization proposed by Azwar [28] in Table 4.
Table 4. CVR Category Criteria

\begin{tabular}{|c|c|}
\hline Indicator & Statement \\
\hline \multirow[t]{3}{*}{$\begin{array}{l}\text { Feasibility of } \\
\text { content and } \\
\text { existing } \\
\text { indicators }\end{array}$} & $\begin{array}{l}\text { 1. The feasibility of the statements } \\
\text { and the element analysis } \\
\text { indicator (matching and } \\
\text { classifying). (Items 1-4) }\end{array}$ \\
\hline & $\begin{array}{l}\text { 2. The feasibility of statements and } \\
\text { relationship analysis indicators } \\
\text { (error analysis). (Item 5-10) }\end{array}$ \\
\hline & $\begin{array}{l}\text { 3. The feasibility of the statement } \\
\text { and the indicators of the } \\
\text { organizing principle analysis } \\
\text { (generalization and } \\
\text { specification). (Items 11-16) }\end{array}$ \\
\hline \multirow{2}{*}{$\begin{array}{l}\text { Completeness } \\
\text { of the } \\
\text { instrument }\end{array}$} & 4. Providing the answer keys. \\
\hline & 5. Providing the scoring rubric. \\
\hline \multirow[t]{3}{*}{ Construction } & $\begin{array}{l}\text { 6. Clarity of the purpose of the } \\
\text { question }\end{array}$ \\
\hline & $\begin{array}{l}\text { 7. Clarity of the instructions for } \\
\text { working on questions }\end{array}$ \\
\hline & $\begin{array}{l}\text { 8. The appropriateness of the } \\
\text { questions and existing material }\end{array}$ \\
\hline \multirow{3}{*}{$\begin{array}{l}\text { Feasibility of } \\
\text { content }\end{array}$} & 9. The appropriateness of material \\
\hline & $\begin{array}{l}\text { 10. Directing the students to think } \\
\text { analytically }\end{array}$ \\
\hline & $\begin{array}{l}\text { 11. The item difficulty level } \\
\text { corresponds to the ability level } \\
\text { of Senior High School students. }\end{array}$ \\
\hline Score of CVR & Category \\
\hline$>0,35$ & Very Useful \\
\hline $0,21-0,35$ & Useful \\
\hline $0,11-0,20$ & Depends on the circumstances \\
\hline$<0,11$ & Not Useful \\
\hline
\end{tabular}




\section{RESULT AND DISCUSSION}

\subsection{Result of analysis of module feasibility test}

The result of the analysis of the module feasibility test (18 indicators) from six expert lecturers is presented in Table 5.

Table 5. Result of analysis of module feasibility test based on Ideal Assessment Criteria in Scale 5

\begin{tabular}{|c|c|c|c|c|c|c|}
\hline \multirow[t]{2}{*}{$\begin{array}{l}\text { Vali- } \\
\text { dator }\end{array}$} & \multicolumn{2}{|c|}{$\begin{array}{l}\text { Content } \\
\text { Aspect }\end{array}$} & \multicolumn{2}{|c|}{$\begin{array}{l}\text { Language } \\
\text { Aspect }\end{array}$} & \multicolumn{2}{|c|}{$\begin{array}{l}\text { General } \\
\text { Score }\end{array}$} \\
\hline & $\begin{array}{l}\text { Ave- } \\
\text { rage }\end{array}$ & $\begin{array}{l}\text { Cate- } \\
\text { gory }\end{array}$ & $\begin{array}{l}\text { Ave- } \\
\text { rage }\end{array}$ & $\begin{array}{l}\text { Cate- } \\
\text { gory }\end{array}$ & $\begin{array}{l}\text { Ave- } \\
\text { rage }\end{array}$ & $\begin{array}{c}\text { Cate } \\
- \\
\text { gory }\end{array}$ \\
\hline 1 & 4.14 & $\begin{array}{l}\text { Fea- } \\
\text { sible }\end{array}$ & 4.50 & $\begin{array}{l}\text { Very } \\
\text { Fea- } \\
\text { sible }\end{array}$ & 4.06 & $\begin{array}{l}\text { Fea- } \\
\text { sible }\end{array}$ \\
\hline 2 & 3.64 & $\begin{array}{l}\text { Fea- } \\
\text { sible }\end{array}$ & 3.25 & $\begin{array}{l}\text { Quite } \\
\text { Fea- } \\
\text { sible }\end{array}$ & & \\
\hline 3 & 4.64 & $\begin{array}{l}\text { Very } \\
\text { Fea- } \\
\text { sible }\end{array}$ & 4.50 & $\begin{array}{l}\text { Very } \\
\text { Fea- } \\
\text { sible }\end{array}$ & & \\
\hline 4 & 4.36 & $\begin{array}{l}\text { Very } \\
\text { Fea- } \\
\text { sible }\end{array}$ & 3.00 & $\begin{array}{l}\text { Quite } \\
\text { Fea- } \\
\text { sible }\end{array}$ & & \\
\hline 5 & 4.00 & $\begin{array}{l}\text { Fea- } \\
\text { sible }\end{array}$ & 3.75 & $\begin{array}{l}\text { Fea- } \\
\text { sible }\end{array}$ & & \\
\hline 6 & 4.00 & $\begin{array}{l}\text { Fea- } \\
\text { sible }\end{array}$ & 3.75 & $\begin{array}{l}\text { Fea- } \\
\text { sible }\end{array}$ & & \\
\hline
\end{tabular}

Based on Table 5, the module is generally feasible to be used in physics learning on Mechanics topic. The general score obtained is 4.06 from a maximum point of 5.00. The general score is obtained from an average score of the result of the module feasibility test, both in the content aspect and language aspect. Conforming to Ideal Assessment Criteria proposed by Azwar [31], all the scores obtained have reached (or exceed) the quite feasible category. Accordingly, the module could be used in physics learning on Mechanics topic and has consistency toward all validator comments that the module is feasible but with revision. Furthermore, the revision is written in reference to validator comments and adapted to the literature. It means that after a revision is written, the Mechanics Based Learning module is feasible to be used in physics learning on Mechanics topic.

Table 5 shows 5 from 6 validators have more interest in the content aspect than the language aspect. The language aspect of the module should be improved in many indicators. On the other hand, the content aspect is considered to have a higher level of feasibility. The lowest average score for the content aspect is obtained from Validator 2 which is 3.64, but still in the feasible category. For more detailed information, the indicators should be improved according to Validator 2 is presented in Figure 2.

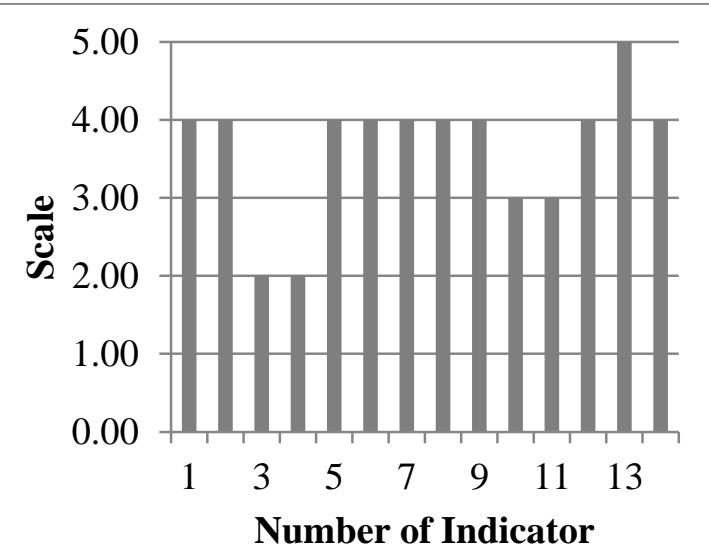

Score

Figure 1. Diagram of the module feasibility test result of the content aspect of the Validator 2.

Figure 1 shows Validator 2 appraised that the content aspect of the module should be improved in many indicators. But, indicator number 13 obtains a perfect score that is 5.00. It could be assumed that the indicator "The clarity and effectiveness of the images used" is very feasible. Meanwhile, indicators should be improved is presented by the lowest score found in indicators numbers 3 and 4 which is equal to 2.00. Indicator number 3 is about the feasibility of the material and its details toward PBL syntax, then indicator number 4 is regarding the feasibility of the problem orientation to the aim. Moreover, the result of the feasibility test for the content aspect that received low scores is found in indicators number 10 and 11 , which were 3.00. Indicator number 10 is the statement "Preparation of activities supporting the ability of scientific literacy." and indicator number 11 is the statement "Preparation of activities supporting the ability to think analytically." These four indicators are related to each other. The reason for the low score of these indicators is found in Validator 2's comment that 
the substance of the module did not present the characteristics of PBL. Due to the characteristics of problems in PBL that should involve various scientific disciplines, the problems in this module does not indicated it.

Validator 2 gave an opinion that PBL ought to presents real-world problems related to the learning material. Consequently, students could learn the learning topic through problem-solving using a multidisciplinary approach. The opinion of Validator 1 is following theory that the main component of PBL is daily-life-problems. Complying with Theory of Constructivism from Carriger [16] and Phumeechanya[18], Problem Based Learning (PBL) ought to also provide interdisciplinary problems in daily life. Hence it could conclude that this Mechanics Problem Based Learning could measure analytical thinking skill by using scientific process through the daily-life-problems. The scientific process used is relating the problems with other disciplines, then it would make the student have interdisciplinary understanding. For that reason, the students have already improved analytical thinking skill to solve problems through a scientific process. This module has passed a revision step yet, this is re-analyzing every problem contained in the module to fulfill the interdisciplinary understanding. Moreover, each problem that does not present scientific disciplines would be added illustrative problems of analytical thinking skills.

Back to Table 1, it could be concluded that the lowest result of feasibility test aspects of the module language is obtained from Validator 4. The lowest average score for language aspects was obtained from Validator 4, which was 3.00, but still in the quite feasible category. For more detailed information, here is a diagram of the result of the feasibility test of the language aspects according to Validator 4.



Figure 2. Diagram of the module feasibility test result of the language aspect of the validator 4 .
Figure 2 shows that Validator 4 has a low interest in the language aspects of the module. This is proved by the uniform score of only 3.00. Validator 4 gave comments that the sentence structure in the module ought to be simplified and maintain the consistency of the sentence. Unrelated information should not need to be elaborated too much. Many sentences use "vector" or "scalar" writing on the module that did not appropriate. Then the sentences and images layout needs to be tidied up. Validator 4's opinion is following the literature from Pratowo [11] that module is a teaching material that is arranged systematically in a language that is easy to understand. Then, Celik [18] and Basilotta Gómez-Pablos [19] stated that the module use simple, easy to understand, and use commonly used terms instructions. In consequent, comments from Validator 4 become an important correction for the revision of this module, so the module could be simple, communicative, and systematic.

The result of the study showed that the Mechanics Problem Based Learning module is generally feasible to be used on physics learning on Mechanics topic with revisions, both content aspect and language aspect. The module is revised based on validators' comments and adapted to the theory. This module has a general feasibility score of 4.06, accordingly it is included in the feasible category.

\subsection{Result of analysis of questions validity test}

The result of the module questions validity tested by six physics lecturers from three state universities in Indonesia based on indicators of the questionnaire is presented in Table 6.

Table 6. Result of module questions validity based on CVR analysis by Lawshe [29] and categorization by Azwar [28]

\begin{tabular}{|c|c|c|c|}
\hline Indicator & $\begin{array}{c}\text { Sub } \\
\text { Indicator } \\
\text { number }\end{array}$ & CVR & Category \\
\hline $\begin{array}{c}\text { Feasibility } \\
\text { content with } \\
\text { indicators }\end{array}$ & 1 & 1 & Very Useful \\
\cline { 2 - 4 } & 2 & 1 & Very Useful \\
\hline $\begin{array}{c}\text { Completeness of } \\
\text { the instrument }\end{array}$ & 4 & 1 & Very Useful \\
\cline { 2 - 4 } & 5 & 1 & Very Useful \\
\hline Construction & 6 & 1 & Very Useful \\
\cline { 2 - 4 } & 7 & 1 & Very Useful \\
\hline
\end{tabular}




\begin{tabular}{|c|c|c|c|}
\hline & 8 & 1 & Very Useful \\
\hline \multirow{2}{*}{$\begin{array}{c}\text { Content / } \\
\text { substance } \\
\text { feasibility }\end{array}$} & 9 & 1 & Very Useful \\
\cline { 2 - 4 } & 10 & 1 & Very Useful \\
\hline \multirow{2}{*}{ Language } & 11 & 1 & Very Useful \\
\cline { 2 - 4 } & 12 & 1 & Very Useful \\
\cline { 2 - 4 } & 13 & 1 & Very Useful \\
\cline { 2 - 4 } & 14 & 1 & Very Useful \\
\hline
\end{tabular}

The result of the validity question test shows that the set of questions is valid in each indicator inside and included in the very useful category. This result is indicated by the score of each sub-indicator which is above 1 . The validators' comments on the question validity test express that questions are generally valid in each indicator.

This module could become a new and better alternative for teaching materials since Hendriana [21] asserted a module is a teaching material that has many good characteristics. Besides, Celik [19] and Basilotta Gómez-Pablos [19] that the PBL module could improve analytical thinking skill. According to Argaw [15] the PBL module has the main component namely daily-life problems. So the PBL module is able not only as teaching material but also to measure the level of analytical thinking skill.

Table 6 shows that indicator 5 obtains the lowest score of 4.2. Owing to the categorization of question validity test based on the theory of Azwar [28], the score is still in a very useful category. The indicator "Language" consist of three sub-indicators, namely "obeying the rules of proper and appropriate Indonesian language", "using communicative language", and "clear sentences". There is a validator's suggestion that the information in the module ought to be more focused on delivering mechanics topic, whereas for information out of topic is explained as necessary. Due to the analysis of the questions validity test, the set of questions is in the very useful category. Furthermore, another validator's comment in the question validity test is the questions in the module are not in simple way. There are some language features not conforming to the rules of proper and appropriate Indonesian language. Some question sentences and images also do not conform with the concept. Thereupon the sub-indicators of question validity test is revised namely structure of sentences, picture and sentence layout, and simplicity of sentences.

Due to the result of questions validity, a set of questions in the module is valid. It means that the module is not only feasible to be used in physics learning on Mechanics topic but also able to measure the level of students' analytical thinking. Conforming with the study result of Celik [19] and Basilotta Gómez-Pablos [19], the Mechanic based learning module provides problem-based questions that could be used to measure and improve students' analytical thinking skills. Besides, according to the Prastowo [11], Yanti [12], and Anatolevich [13], this Mechanic based learning module has fulfilled the criteria for a good module. Hence the Mechanics based learning module could be used for physics learning on Mechanics topic and able to measure the level of students' analytical thinking. Wherefore this module could be used by teachers as teaching materials.

Owing to the result of the question validity test, the set of questions in the module is valid for each indicator. The set of questions in the module is included in the very useful category. It could be indicated by the result of CVR techniques on each subindicator of assessment aspects that are worth 1 . Thus, the set of questions in the module is valid to measure the level of thinking analysis on physics learning on Mechanics topic with revisions.

\section{CONCLUSIONS AND SUGGESTIONS}

\subsection{Conclusions}

The result of the study shows that the Mechanics problem based learning module is feasible to be used in physics learning on Mechanics topic. Module feasibility test is analyzed by using Ideal Assessment Criteria in scale 5 and obtain score of 4,06. Due to the categorization by Azwar [28], the module is in a feasible category to be used in physics learning on Mechanics topic. Based on the analysis result of the question validity test, it obtained a score of 1 as a perfect score in all sub-indicators. And owing to the categorization by Azwar [28], the set of questions in this module is included in the very useful category. It means that the questions in this module are valid. The set of questions in this module also fulfill the analytical thinking skill conforming to Bloom's taxonomy.

\subsection{Suggestions}

Based on these conclusions it is suggested: (1) to make module accomplishing syntax third and fifth steps that need real experiment to the students, (2) to be continued on phase ii research (pilot project stage) with spesific indicators for each question in the quetionnaire; and (3) to conduct a similar research that 
could improve analytical thinking skills in physics learning on Mechanics topic.

\section{AUTHORS' CONTRIBUTIONS}

Setiaji, B. was an adviser for the research. Setiaji, B. conceived of the presented idea. Sekarini, Y. P., Adiningsih, E. T., and Anisa, Z.L choose the topic for PBL module and Mechanics topic. Sekarini, Y. P. wrote the introduction. Setiaji, B. suggested the references for the literature review. Adiningsih, E., T., and Sekarini, Y. P.wrote the literature review. Setiaji, B. reviewed the literature used. Setiaji, B. give instructions about the methodology. Anisa, Z.L., and Sekarini, Y. P. performed the methodology then Setiaji, B. verified the analytical methods.

Sekarini, Y. P. led and. coordinated all team members. Setiaji, B. guided all authors to build writing outline of the questions to fulfill the analytical thinking skill indicators based on Bloom's Taxonomy. Sekarini, Y. P. divided Mechanics materials for 3 parts to Sekarini, Y. P., Adiningsih, E. T., and Anisa, Z.L. Sekarini, Y. P. wrote Kinematics material, writing outline of questions, and questions for module. Adiningsih, E. T. wrote Force material, writing outline of questions, and questions for module. Anisa, Z.L. wrote Newton's Law material, writing outline of questions, and the questions for module. After that, Sekarini, Y. P. collected and designed the module for whole package. Setiaji, B. reviewed the modul and gave comments. All authors discussed the module and then revised the module.

Setiaji, B. gave validators contacts to Sekarini, Y. P., Adiningsih, E. T., and Anisa, Z.L. Then, Sekarini, Y. P., Adiningsih, E. T., and Anisa, Z.L. contact the validators to review the module with questionnaire of the module feasibility test and questions validity test. The validators gave scores and suggestions on the questionnaire. Then, Sekarini, Y. P., Adiningsih, E. T., and Anisa, Z.L. revised the modules based on validators' comments and adapted to the theory.

Sekarini, Y. P., performed the analysis of module feasibility test and wrote the result on the manuscript. Adiningsih, E. T., and Anisa, Z.L performed the analysis of question validity test and wrote the result on the manuscript. Anisa, Z.L. wrote conclusion. Sekarini, Y. P. collected the references from Mendeley. After that, Sekarini, Y. P. collected all parts and arranged the manuscript. All authors discussed the result and commented on the manuscript.

Sekarini, Y. P., Adiningsih, E. T., Anisa, Z.L., and Setiaji, B. contributed to the design of the module, to the validation and revision of the module, to analysis of the research, to the result and conclusion of the analysis, and to the writing of the manuscript.

\section{ACKNOWLEDGMENTS}

Thanks to FMIPA UNY in the framework of "PKM 70 Titles" FMIPA UNY 2020 which has provided research funds to our proposal title, namely: Mechanics Problem Based Learning Module to Improve Student's Thinking Skill on Physics Learning on Mechanics topic. On that account, research can be carried out and can be followed up by author.

\section{REFERENCES}

[1] Sriraman B, Roscoe M. Interdisciplinary perspectives to the development of high ability in the 21th century. Int $\mathbf{J}$ Talent Dev Creat. 2016;3(2).

[2] Putri SMZ, Cari C, Sunarno W. Analysis of Analytical Thinking and Misconceptions on the Concepts of Heat and Temperature on Physics Students. In: Journal of Physics: Conference Series. 2019.

[3] OECD. PISA 2018 insights and interpretations. OECD Publ [Internet]. 2019;64. Available from: https://www.oecd.org/pisa/PISA 2018 Insights and Interpretations FINAL PDF.pdf

[4] OECD. PISA 2018 Assessment and Analytical Framework. PISA. OECD Publishing. Paris. 2019.

[5] Sari R, Perdana R, Riwayani, Jumadi, Wilujeng I, Kuswanto H. The Implementation of Problembased Learning Model with Online Simulation to Enhance the Student's Analytical Thinking Skill in Learning Physics. In: Journal of Physics: Conference Series. 2019.

[6] Stentoft D. From saying to doing interdisciplinary learning: Is problem-based learning the answer? Act Learn High Educ. $2017 ; 18(1)$.

[7] Sabaruddin S. Penggunaan Model Pemecahan Masalah Untuk Meningkatkan Kemampuan Berpikir Analisis Peserta Didik Pada Materi Gravitasi Newton. Lantanida J. 2019;7(1). 
[8] Liu T. Learning Difficulties in Theoretical Physics and Teaching Reform Strategies. Mod Appl Sci. 2019;13(11).

[9] Suastra IW, Ristiati NP, Adnyana PPB, Kanca N. The effectiveness of Problem Based Learning Physics module with authentic assessment for enhancing senior high school students' physics problem solving ability and critical thinking ability. In: Journal of Physics: Conference Series. 2019.

[10] Malmia W, Makatita SH, Lisaholit S, Azwan A, Magfirah I, Tinggapi H, et al. Problem-based learning as an effort to improve student learning outcomes. Int J Sci Technol Res. 2019;8(9).

[11] Prastowo A. Panduan Kreatif Membuat Bahan Ajar Inovatif. J Chem Inf Model. 2012;

[12] Yanti FA, Kuswanto H, Mundilarto, Jumadi, Rosa FO. Development of analog material based physics module to improve concept understanding and creative thinking. Int $\mathbf{J}$ Sci Technol Res. 2019;8(10).

[13] Anatolevich MA, Vasilyevna KN. Methods of teaching interdisciplinary module of physics and Informatics. Perspekt Nauk i Obraz. 2018;33(3).

[14] Arends RI, Kilcher A. Teaching for student learning: Becoming an accomplished teacher. Teaching for Student Learning: Becoming an Accomplished Teacher. 2010.

[15] Argaw AS, Haile BB, Ayalew BT, Kuma SG. The effect of problem based learning (PBL) instruction on students' motivation and problem solving skills of physics. Eurasia J Math Sci Technol Educ. 2017;13(3).

[16] Carriger MS. Problem-based learning and management development - Empirical and theoretical considerations. Int J Manag Educ. 2015;

[17] Phumeechanya N, Wannapiroon P. Ubiquitous Scaffold Learning Environment Using Problembased Learning to Enhance Problem-solving Skills and Context Awareness. Int J Integr Technol Educ. 2013;

[18] Celik P, Onder F, Silay I. The effects of problembased learning on the students' success in hysics course. In: Procedia - Social and Behavioral Sciences. 2011.

[19] Basilotta Gómez-Pablos V, Martín del Pozo M, García-Valcárcel Muñoz-Repiso A. Project- based learning (PBL) through the incorporation of digital technologies: An evaluation based on the experience of serving teachers. Comput Human Behav. 2017;

[20] Assegaff A, Sontani UT. Upaya Meningkatkan Kemampuan Berfikir Analitis Melalui Model Problem Based Learning (Pbl). J Pendidik Manaj Perkantoran. 2016;1(1):38.

[21] Hendriana H, Johanto T, Sumarmo U. The role of problem-based learning to improve students' mathematical problem-solving ability and self confidence. J Math Educ. 2018;9(2).

[22] Arends RI. Learning to Teach. Tenth Edit. New York: McGraw-Hill Education; 2014.

[23] Krathwohl. Revision of Blooms Taxonmy. Am J Psychol. 2009;

[24] Permana TI, Hindun I, Rofi'ah NL, Azizah ASN. Critical thinking skills: The academic ability, mastering concepts and analytical skill of undergraduate students. J Pendidik Biol Indones. 2019;5(1).

[25] Reddy MVB, Panacharoensawad B. Students Problem-Solving Difficulties and Implications in Physics: An Empirical Study on Influencing Factors. J Educ Pract. 2017;8(14).

[26] Bloom BS, Krathwohl DR. Taxonomy of Educational Objectives: The Classification of Educational Goals. In: Handbook I: Cognitive Domain. 1956.

[27] Thiagarajan S. Instructional development for training teachers of exceptional children: A sourcebook. J Sch Psychol. 1974;

[28] Azwar S. Reliabilitas Dan Validitas Item. Bul Psikol. 2016;3(1).

[29] Lawshe Ch. A Quantitative Approach to Content Validity. Pers Psychol. 1975; 